\title{
Application of MIKE 21 in a multi-purpose floodway zoning along the lower Hungarian Drava section
}

\author{
Szabolcs CZIGÁNI ${ }^{* *}$, Ervin PIRKHOFFER ${ }^{1}$, Ákos HALMAI ${ }^{1}$, Dénes LÓCZY1 \\ ${ }^{1}$ Department of Physical and Environmental Geography, Institute of Geography, Hungary \\ Received 10 June 2016; Revised 11 July 2016; Accepted 21 November 2016 \\ *Correspondence to: Szabolcs CZIGÁNI, e-mail: sczigany@gamma.ttk.pte.hu
}

\begin{abstract}
Floodway delineation, zoning and hydrodynamic modelling for a section of the Drava River was carried out with MIKE 21 software at a one-time input flood pulse of $3000 \mathrm{~m} \mathrm{~s}^{3} \mathrm{~s}^{-1}$ discharge. The objective of the current study was the delineation and mapping of floodway zones in the form of a set of georeferenced GIS data for the section between Őrtilos (river kilometer $236 \mathrm{~km}$ ) and Drávaszabolcs $(70.2 \mathrm{~km})$. Zonation was based on water velocities. Four zones were delineated upstream Barcs, and three between Barcs and Drávaszabolcs, where, due to the confined floodplain downstream Barcs, no stagnant water area was identified. Specific velocities ranged between 0.089 and $3.476 \mathrm{~m}^{2} \mathrm{~s}^{-1}$ and 0.075 and $2.01 \mathrm{~m}^{2} \mathrm{~s}^{-1}$ upstream and downstream Barcs, respectively, markedly lower than stated in the Government Decree $\left(0.2\right.$ to $\left.6.0 \mathrm{~m}^{2} \mathrm{~s}^{-1}\right)$. The primary and secondary conveyance zones covered a combined area of about $40 \%$ of the entire floodplain, while the remaining $60 \%$ included both the transitional and stagnant water zones upstream Barcs and solely the transitional zone downstream Barcs. Our analyses help to mitigate the effects of flood peaks and provide information for decision makers and local stakeholders on flood management tasks.
\end{abstract}

\section{KEYWORDS}

2D hydrological modelling; Design Flood Level; floodway; LiDAR; DEM; Drava River

\section{Introduction}

Climate change and antropogenic effects on land use have profoundly altered runoff regimes and floodpain flow characteristics along the rivers of Hungary (Lovász et al., 2007; Novák et al., 2013; Rózsa and Novák, 2011). The need for flood control in Hungary is justified by relatively constant peak flow values and flood waves but increasing peak water levels that reached record heights in the years 2002, 2006 and 2013. Water management experts, however, widely agree that in the future efficient 
flood prevention and defense has to be founded on more detailed topographic and bathymetric surveys complemented with computer models (Czigány et al., 2007).

An ongoing project (Water management mapping: Mapping flood risk and preparing strategic risk management plans) aims at exploring the physical background knowledge of floods to be utilized in floodway management planning (Government of Hungary, 2014). The floodway is that portion of the floodplain which is effective in carrying flow (FEMA, 2013). In Europe the term active floodplain is used for this zone (Marriott and Alexander, 1999). Floodway management plans include zoning of the floodway and proposals for imposing restrictions (of construction, land use, etc.) in the various zones (FEMA, 2013). While in the United States it is officially sufficient to distinguish between the floodway and the floodway fringe (inundated during 1\%-probability floods), Hungarian regulation (Government of Hungary, 2014) requires a finer distinction between floodplain zones.

For the analysis of water flow in river channel and floodplains various types of numerical models have been used: one-dimensional finite difference hydraulic models (Mishra et al., 2001), twodimensional finite difference and finite element hydraulic models (Gee et al., 1990; Bates et al., 1992), and two-dimensional finite element hydraulic models coupled with hydrologic models (Bates et al. 1996, 2006; Stewart et al., 1999; Jung et al., 2012) and physical downscale models, such as flumes and sand tables (Bertalan et al., 2016). Remote sensing and GIS applications are commonly associated with hydrodynamic modelling and may provide additional data to increase reliability (Liu and De Smedt, 2005).

One of the most challenging problems with numerical modeling of flow through river reaches stems from the complexity of channel and floodplain geometry (Babaeyan-Koopaei, 2003), floodplain roughness (Bedient and Huber, 2002) and shear velocity. Besides geometric limitations, numeric models are further burdened with numerical simplification (i.e. omission of terms or fluid properties), or the use of empirical correlations (Toombes and Chanson, 2011). The resolution of models usually differs for the channel and the floodplain (the floodway and the floodway fringe, which is inundated with $1 \%$ probability). For management reasons, however, a uniform approach is desirable (Szabó et al., 2012; Grêt-Regamey et al., 2015). Therefore, modelling should focus on the flow interface (the velocity profile in the environs of river banks) between the main channel and the floodplain. For similar reasons, it is desirable to have fine grid spacing at the walls to capture the velocity profile near the boundary (Bates et al., 2006).

The staff of the Department of Physical and Environmental Geography, Institute of Geography, University of Pécs, is engaged in hydromorphological and geoecological investigations of floodplains with special attention paid to the Hungarian section of the Drava River. Broad experience has been gathered in hydrological modelling and GIS visualization of various water management issues, first of all, the physico-geographical factors contributing to the generation of flash floods in mountain and hill environments. A recent Government Decree (Government of Hungary, 2014) prescribes the preparation of management plans for the floodways for all major rivers in Hungary. Under contract with the South-Transdanubian Water Management Directorate (DDVíZIG), experts of the Department undertook the task of modelling the floodway of the Drava River, the border river between Hungary and Croatia for the section between the river kilometers 154.1 and 70.2 (Fig. 1). Supplementing the existing one-dimensional model (Torma et al., 2014), a 2D hydrodynamic model had to be constructed. The 2D simulation results serve practical design goals: the management of the active floodplain to ensure the safe conveyance of flood waves and the maintenance of optimal conditions from the aspect of water management.

The purpose of modelling was the identification of four zones on the map of the floodway based on specific velocity as well as in the form of a set of georeferenced GIS data: (i) the primary floodway zone; (ii) the secondary floodway zone; (iii) a transitional zone and (iv) the stagnant water area (including counter-current flow), and to compare 2D results with a 1D model generated in HEC-RAS 4.1 by Józsa et al. (2013) with 300 input cross-sectional geometry data. 
Zoning was executed for the current situation and future conditions after development. Through the interpretation, the topographic data the channel and the boundaries of zones had to be referred to the channel edge at bankfull stage. In hydrodynamic modelling, the trends and causes of temporal changes in the hydromorphology of the floodway and its fringe had to be revealed focusing on the combined impact of natural and human-induced processes.

The model of dynamic floodplain zones provides valuable assistance to the planning of channel and floodplain management, including legal restrictions for construction activities, guidelines for insurance of property and optimization of floodway vegetation from the aspect of safe flood conveyance.

\section{Methods}

The 2D hydrodynamic modelling of the selected Drava floodplain segment was performed by the MIKE 21 flexible Mesh Model developed in
Hørsholm, Denmark (DHI, 2014). MIKE 21 is the leading software package for 2D modelling of hydrodynamics, waves, sediment dynamics, water quality and ecology. MIKE 21 is a modular product and includes simulation engines that are aimed at a very wide range of applications. These include modelling of tidal flows, storm surge, advectiondispersion, oil spills, water quality, mud transport, sand transport, harbour disturbance and wave propagation. MIKE 21 has a menu-driven user interface. The installation also includes manuals, including step-by-step manuals and examples. This model is composed of shallow-water equations, vertically averaging the set of the three-dimensional Navier-Stokes equations, which describes fluid flow but cannot be solved analytically. Since there are several orders of magnitude differences between the investigated water depth and the horizontal extension of the model area, this approach is an acceptable simplification for the implementation of the given task (Weber and DeGiano,1996). The horizontal velocity vectors are assumed to truly depict the studied flow processes.

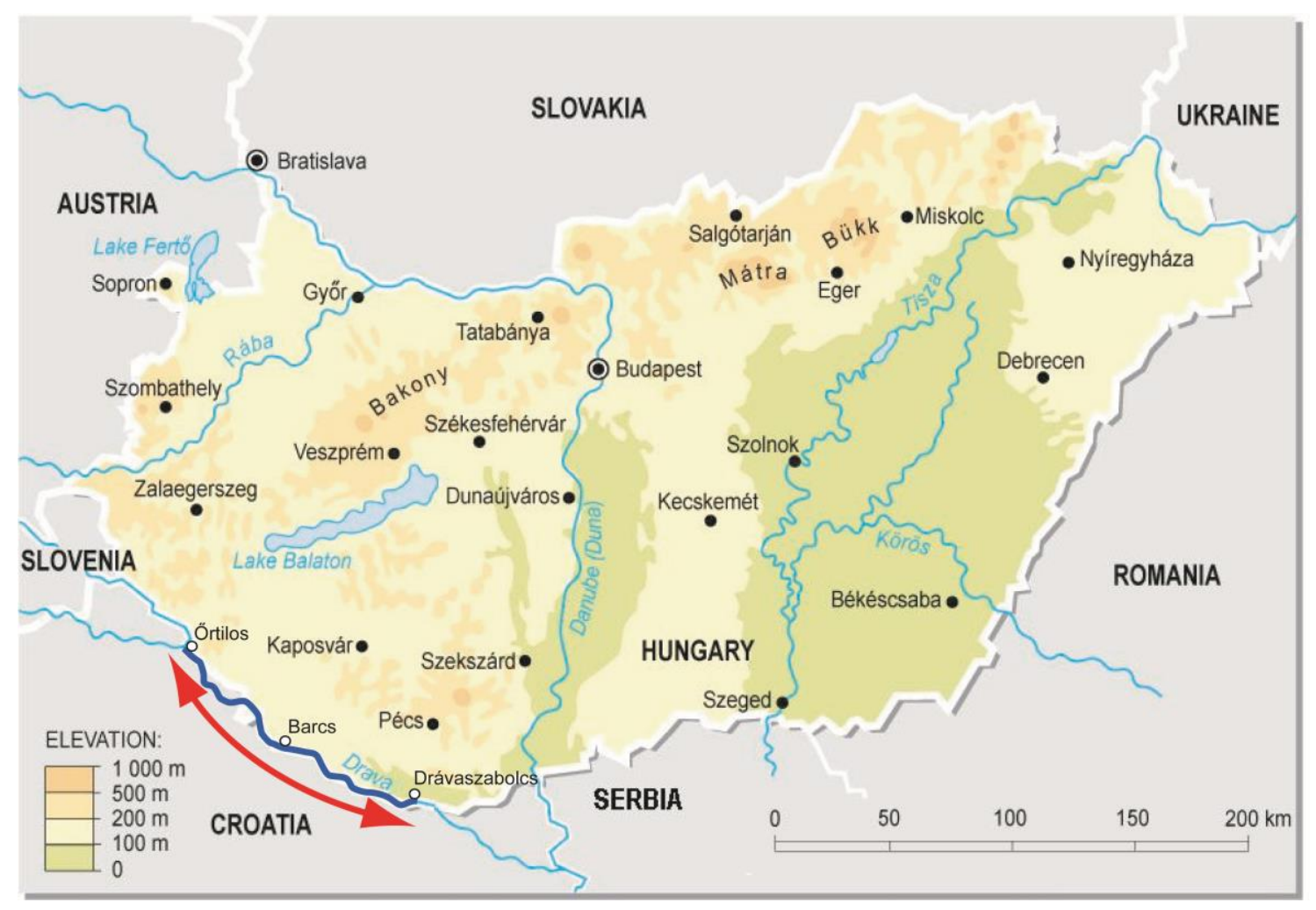

Figure 1 Location of the studied reach of the Drava River 
The base equations are solved using an unstructured discretization mesh, which equally includes elements of a triangular irregular network (TIN) and a quadrangular network (Mavriplis, 2008). Thus, the sizes and shapes of the individual elements are variable. The model relies on the Finite Volume Method (Chen, 2010) for the solution of partial differential equation system, which calculates water depth and specific flow values in $x$ and $y$ directions. Further derived values include water level, current velocity and shear stress on the channel floor. The model is static and does not need timesteps definition since the highest stable time step for a given element is selected based on the CFL condition from a predefined province and treated automatically.

\subsection{Data input}

The following input data were used for model setup: (i) calculation grid; (a) filled from ground elevation data; (b) filled with smoothness coefficients; (ii) boundary conditions; (iii) initial conditions; (iv) model parameters.

The basis of the model running were flood wave curves and discharge values used for determination of the levels constituting the input of the Design Flood Level (DFL) model (Budapest Technical University - Józsa et al., 2013).

First we filtered an 8 points per square meter resolution classified ('model key' and 'ground') point cloud to generate a general elevation raster that did not include the river surface. Secondly the river bed geometry was created from the cross-sectional data and subsequently a combined DEM was compiled (Fig. 4). Bank lines were generated using cross sections and orthoimagery, produced by stereophotogrammetry (DDKÖVIZIG, 2000). The final combined raster had a resolution of 1 by 1 meter per pixel.

\subsection{Digital Elevation Model and channel delineation}

With a spatial resolution of 1 by 1 meter calculations take an excessively long time. To overcome this challenge, a mesh was generated using the flexible mesh model of MIKE 21 with a spatial resolution of 1-meter for the river and 25-meter for the floodplain. This way we optimized output data quality and this mesh size meant adequately short processing time.

River channel morphological parameters were imported from the cross-sections of the Hydrographical Atlas of the Drava River (DDKÖVIZIG, 2000). The interval between crosssections was $350 \mathrm{~m}$ along the reaches entirely on Croatian territory and $50 \mathrm{~m}$ for those entirely on the Hungarian territory.

The floodway model also covers the sidechannels, which were surveyed in 2010-2013 within the framework of a joint Hungarian - Croatian IPA landscape rehabilitation project (Purger, 2013). As part of the project, four side-channels (two at Drávatamási, one at Tótújfalu and one at Drávapalkonya) were rehabilitated. Altogether eight of the side-channels are incorporated into our model.

For including the parameters of the areas between cross-sections, a linear interpolation method has been elaborated (Fig. 2), based on similitude estimation. Straight alignment was substituted by 50 alignment line segments, and this allowed a high-resolution depiction of channel morphology.

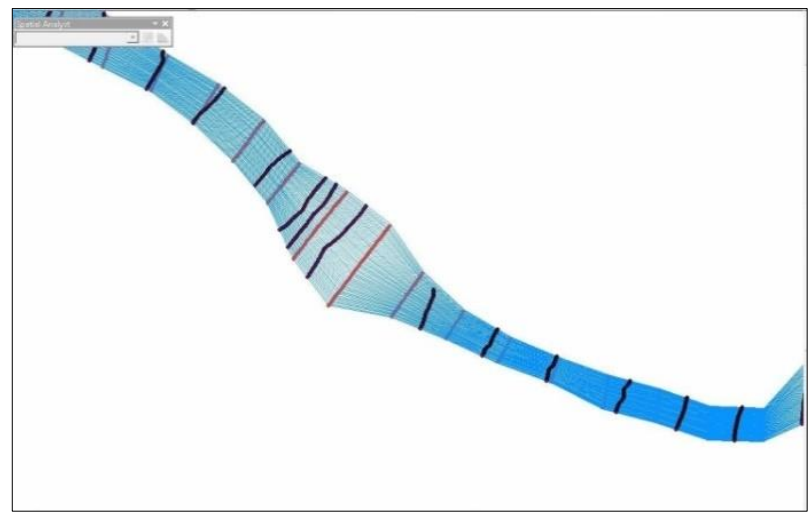

Figure 2 Linear interpolation to depict channel morphology between cross-sections

A source of error is that the channel morphology in the Hydrographical Atlas is rather outdated. It reflects conditions existent during the 
cross-section surveys, which took place 12 years ago and the thalweg and bathymetry of the river bed have changed locally to a considerable extent. Riverbed morphology was subsequently masked by the interpolation of LIDAR data. For correction, the channel bank edge was rectified with the help of high-resolution LiDAR images (Fig. 3) and orthophotos. From the ground points of LiDAR images, the first on either on the left or right bank of the water surface were selected and rectified from the interpretation of orthophotos. The set of ground points were further processed by edge filters, and thus an edge detection for the riverbank was achieved.

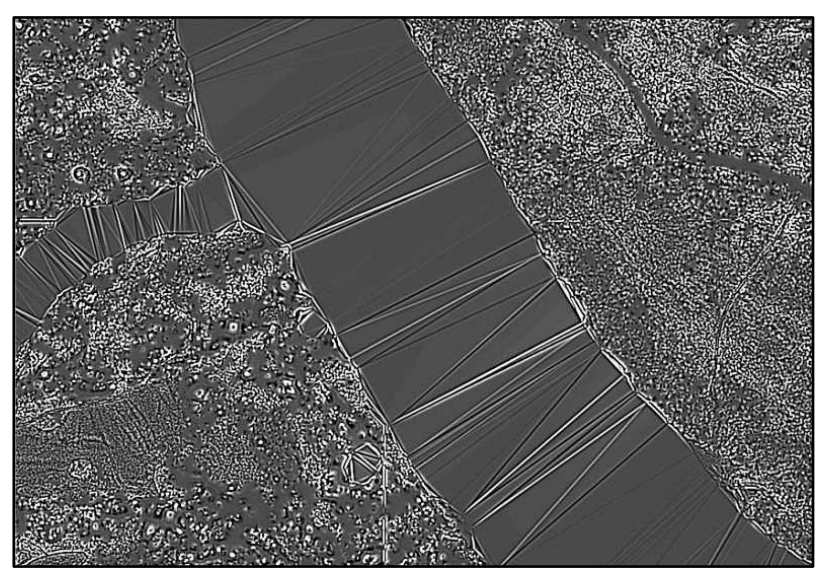

Figure 3 Channel delimitation based on topography from high-resolution LiDAR images using edge filtering

For the digital representation of the riverbank edge at bankfull stage, the DEM was merged with the bathymetry channel model (Fig. 4). The uniform model, where the channel limits are defined by the line where medium water level intersects with the $D E M$, is suitable for further high-resolution analyses.

In the next step, to define the $\mathrm{k}$ factor of the hydrodynamic model with high precision, the LiDAR images were interpreted for the identification of land cover through the selection of the dominant reflectance values.

Five major land cover classes were distinguished: zones of low, medium high and high vegetation, ground surface (seasonally appearing as low or medium high vegetation) and artificial structures (buildings) on the surface.

\subsection{Hydrodynamic modeling}

The calculation mesh was produced using the Mesh Generator of MIKE Zero application. Since the software is not able to import GIS data directly and to process them, the first step had to be the preprocessing of data.

The calculation mesh is generated employing line chains, both polygons, and free line chains (Fig. 5). An advantage of the unstructured mesh is that the individual elements can vary in area, and the internal angles of the triangular elements can also be different.

Taking advantage of this, finer resolution (smaller element size) can be defined for the river channel, where higher current velocities and diverse flow patterns are typical, than in the active floodplain, where overbank flow spreads out, and currents form at small water depth and, therefore, the size of elements is usually larger (BabaeyanKoopaei, 2003). Thus, the number of elements can be optimized. This influences the time needed for model running, the size and easy handling of model files. It is not sufficient to identify the study area as a polygon, but further internal polygons are to be defined which signify areas of various size. It was an important goal to minimize the scope of boundary conditions through treating the study area as a single unit.

Imprecise identification of boundary conditions is a major source of error. Therefore, boundary conditions have to be limited to one upper and one lower boundary condition. Also, the spatial resolution of the model (25 and 1 meter, for the floodplain and the riverbed, respectively) has to be in accordance with the technical requirements of floodway management planning. Thus, the number and size of necessary elements are easy to determine.

Consequently, two additional features were introduced to improve the spatial resolution of the mesh: one for the river centerline, and one for the crown level of flood-control levees. The inclusion of the levees is motivated by two reasons. Their size could remain below that of a calculated element, and this means that they are left out from the elevation model used for the hydrodynamic simulation and undoubtedly lead to error. The line chain along the levee crown serves for fitting the calculation mesh. 


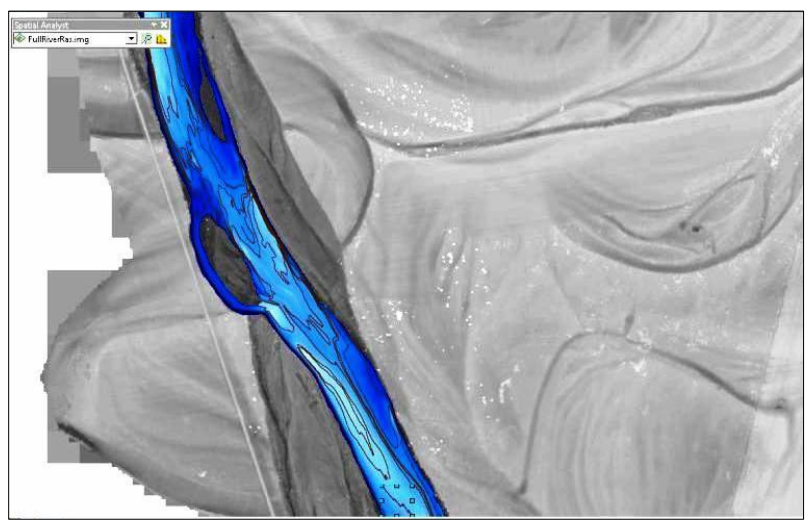

The other reason is that flood-control levees are assumed to be never overtopped and, therefore their representation in the calculations can be superfluous. Given their small size, the elements generated for the levees are much smaller than others in the active floodplain and, thus, the instability, run-time and the number of elements are unnecessarily increased. Therefore, if the water level in the next cell reaches the level of the crown, the levee is overtopped in the model.

Figure 4 Detail of the unified elevation model

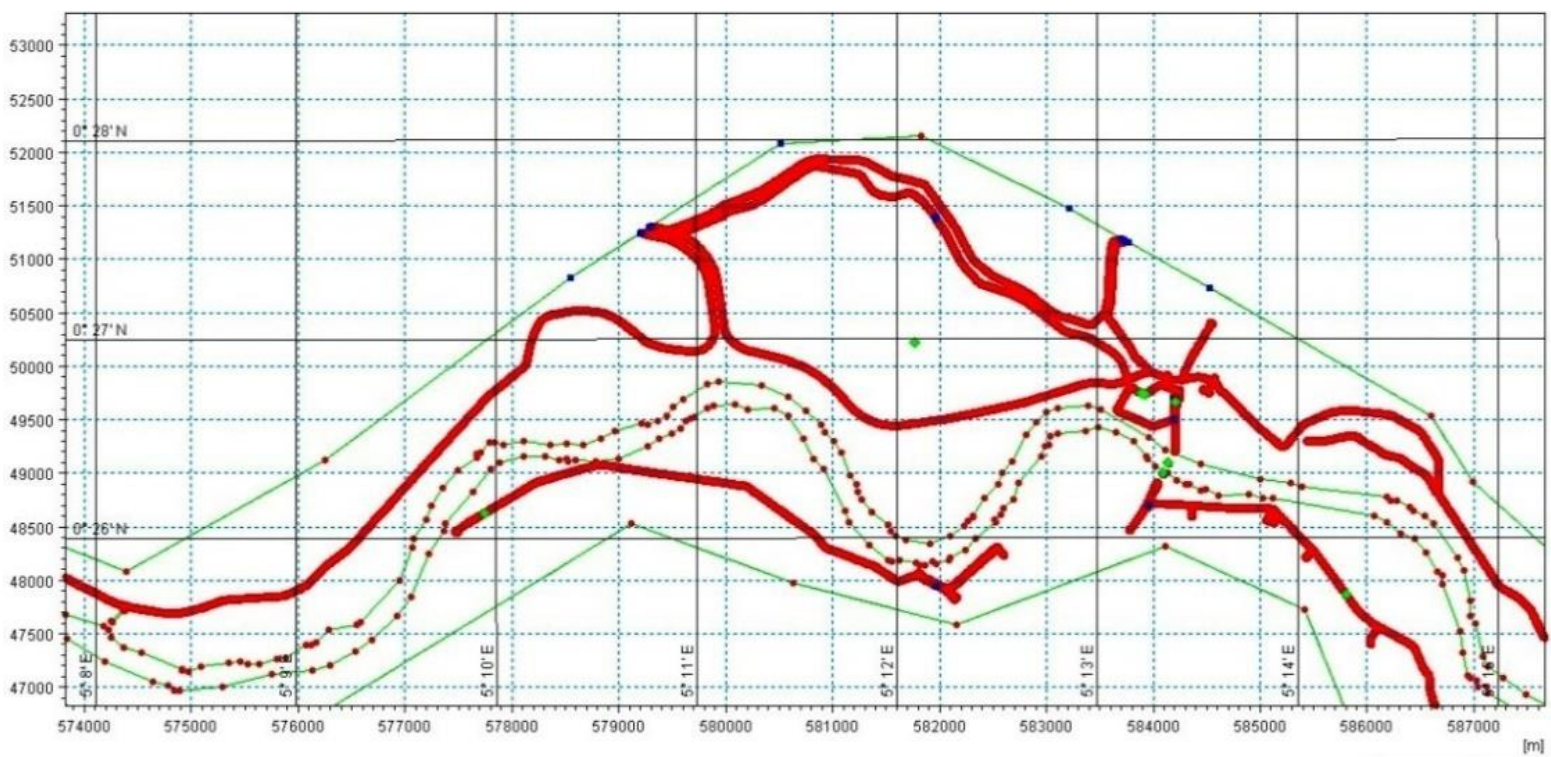

Figure 5 Detail of line chains representing the river channel and flood-control levees created by Mesh Generator

Our objective being the modelling of water flow, only those elements of topography that influence water flow are included in the model. For mesh generation, a corrected set of breakpoints was applied. The distance between two breakpoints determines the opposite internal angle and area of the triangular elements. The shorter the distance, the smaller are the angle and the area and local model sensitivity is proportionally enhanced. Excluded from the calculation mesh, the piers of the two road bridges along the study reach were incorporated into the model with a simplified geometry (Fig. 6).
The maximum allowable size for channel elements (represented by triangles) was $2,000 \mathrm{~m}^{2}$ and for floodplain elements $20,000 \mathrm{~m}^{2}$. This is the limit to which the software can increase the area of elements where no other condition applies.

Three kinds of boundary conditions are identified. The line chain attributes are explained as 0 means a simple line chain; 1 is model boundary (without a perpendicular component of velocity); 2 is the upper boundary condition (incoming flow); 3 is the lower boundary condition (fixed water level). 


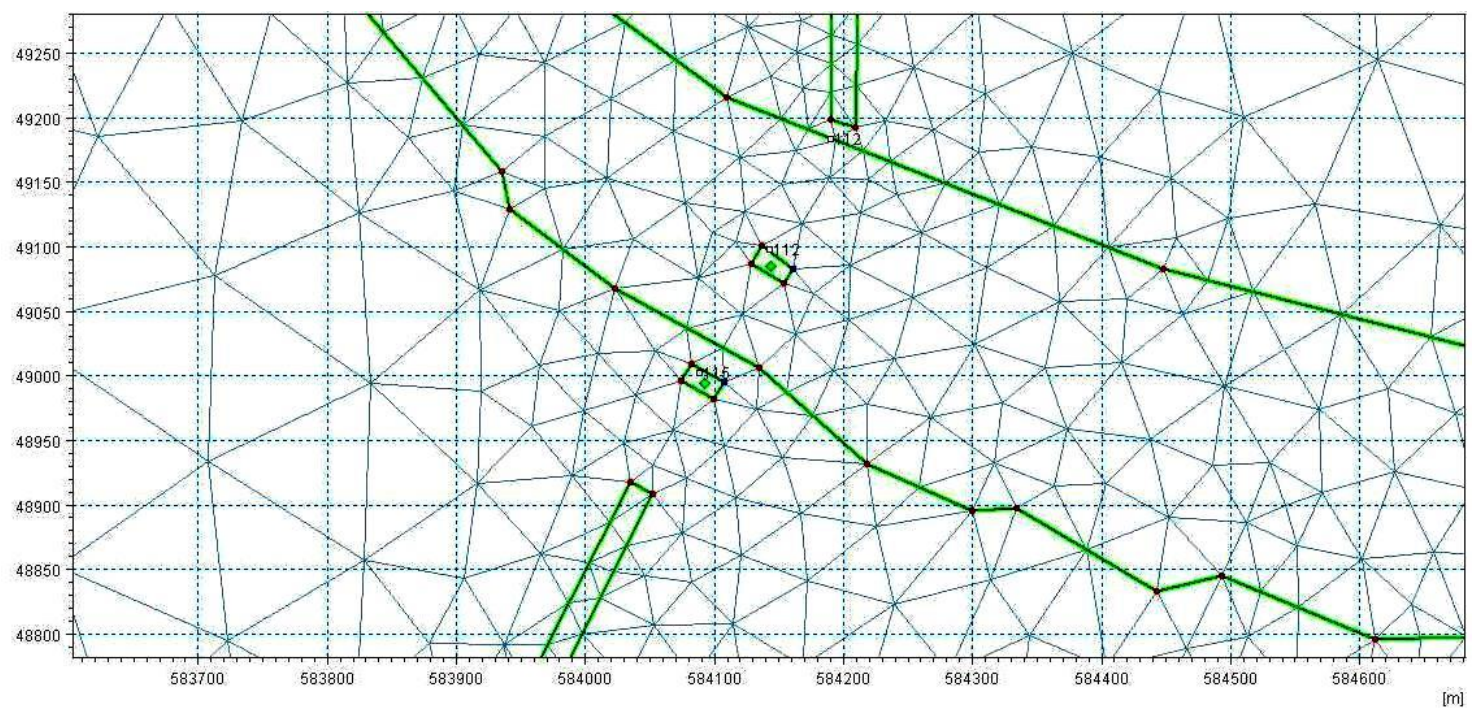

Figure 6 Representation of the piers of the Drávaszabolcs road bridge in the model

Following the above preparatory steps, the mesh was generated with the parameters: maximum permitted element area, the number of elements and minimal internal angle of elements. The last parameter is an important factor of stability, limited by the angles of line chains (to $28^{\circ}$ in the presented model). The resulting mesh is smoothed in several steps until the final mesh is reached (Fig. 7).

Then the final mesh is parametrized with topographic and smoothness data (represented by $z$ coordinate values).

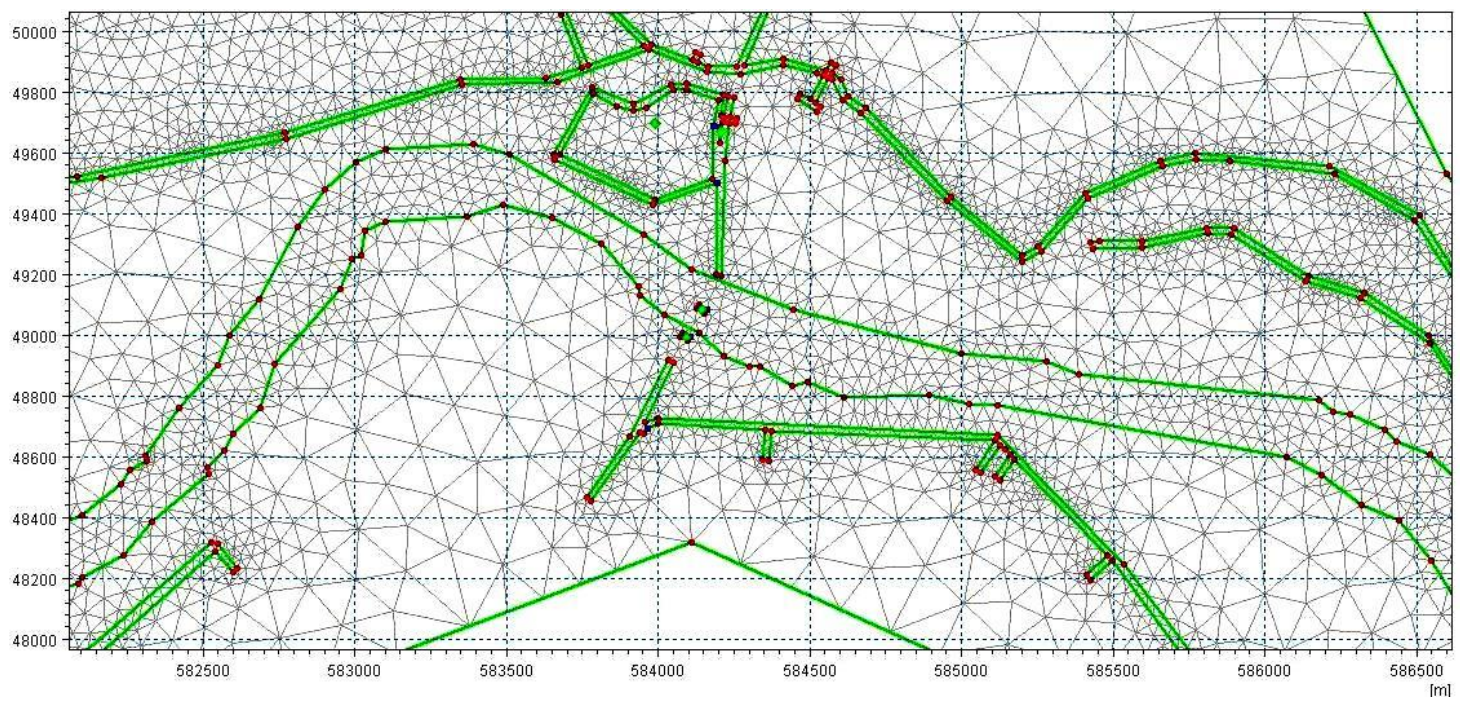

Figure 7 Detail of the final calculation mesh

After interpolation, an elevation model was achieved (Fig. 8). Manning's smoothness (inverse roughness) was defined in four categories: (i) forest $\left(9 \mathrm{~m}^{1 / 3} \mathrm{~s}^{-1}\right)$; (ii) channel $\left(30 \mathrm{~m}^{1 / 3} \mathrm{~s}^{-1}\right)$; (iii) agricultural area $\left(30 \mathrm{~m}^{1 / 3} \mathrm{~s}^{-1}\right)$; (iv) built-up area (sealed surfaces) $\left(50 \mathrm{~m}^{1 / 3} \mathrm{~s}^{-1}\right)$ (Fig. 9). 


\subsection{Boundary conditions}

The upper boundary condition, permanent inflow, was equal to the value used in the modelling of DFL. As the lower boundary condition water level or the Q-h loop, curve may have been acceptable. Since they were not known, current velocity, offered by the software, was employed. This, however, involved some degree of imprecision in the description of boundary conditions. Previous model runs supplied characteristic figures of current velocity as a function of water regime of the studied river. Thus, the lower boundary condition was defined as an outward-directed velocity vector of $0.8 \mathrm{~m} \mathrm{~s}^{-1}$.

Since the design flood passes through the entire width of the floodway, both boundary conditions do not only refer to the channel at bankfull stage, but to the whole delineated floodway.

\subsection{Initial conditions}

The precise identification of initial conditions is inevitable for the success of any numerical modelling. In most of the cases, this means the specification of initial water flow in percentage of bankfull discharge, specific discharges or velocity vectors. In our project, the goal was to specify as an initial condition a water level as close to DFL as possible. This way the time necessary for the simulation can be minimized.

The specification of an initial condition is based on the relatively high stability of the MIKE 21 FM model. With the critical elements removed from the mesh, time steps between 1 and 30 seconds allow rapid running of the model with acceptable imprecision. Problems arise with small-scale elements, for instance, the environs of bridges, where water levels do not converge with the expected values. For the final calculation, however, the time step is highly reduced, and errors disappear after a few time steps.

Consequently, initial conditions of water depth and velocity components with $\mathrm{x}$ and $\mathrm{y}$ directions were identified if inflow equals the discharge corresponding to DFL.

\subsection{Parametrization}

For the MIKE 21, FM hydrodynamic model parametrization was very simple. The dimensions of the modelled phenomenon allowed us to disregard Coriolis force, tensions deriving from wind pressure and ice cover and focus on two parameters.

The software permits distinctions between the inundation and emergence of elements (flooding and drying). Modelling utilizes three parameters which determine limits to the individual elements. Drying depth shows the water depth at which a previously inundated element emerges above the water surface and is qualified dry, while above the flooding depth a previously dry element is inundated but do not take part fully in the calculation. The third parameter is wetting depth: below which an inundated element only takes part in the continuity equation, i.e. the model takes into account the amount of water stored in the element. If this water depth becomes equal to wetting depth, the model applies dynamic equations for the given element, which takes part fully in the current capable of covering further elements with water.

$A$ basic requirement is that these parameters have to unequivocally control the advance rate and final extension of flooding. Therefore, the selection of parameter values must be made with profound knowledge on the study area (vegetation cover, sealed surfaces, microtopography). Using the figures proposed by model developers, drying depth was fixed at $0.05 \mathrm{~m}$, flooding depth at $0.1 \mathrm{~m}$ and wetting depth at $0.2 \mathrm{~m}$.

Another aspect which deserves special attention is eddy viscosity. Since in reality, significant processes take place at scales below mesh resolution (impossible to depict in the model), the losses of energy at subgrid scales cannot be neglected. In our case, the Smagorinsky formula, proposed by the developers, was applied with a constant coefficient of 0.28 (Spalart, 2009). The official definitions of floodplain zone according to the new government decree (Government of Hungary, 2014) A 83/2014. (III.14.) and the limitations on construction activities in the individual zones are shown in Table 1. 


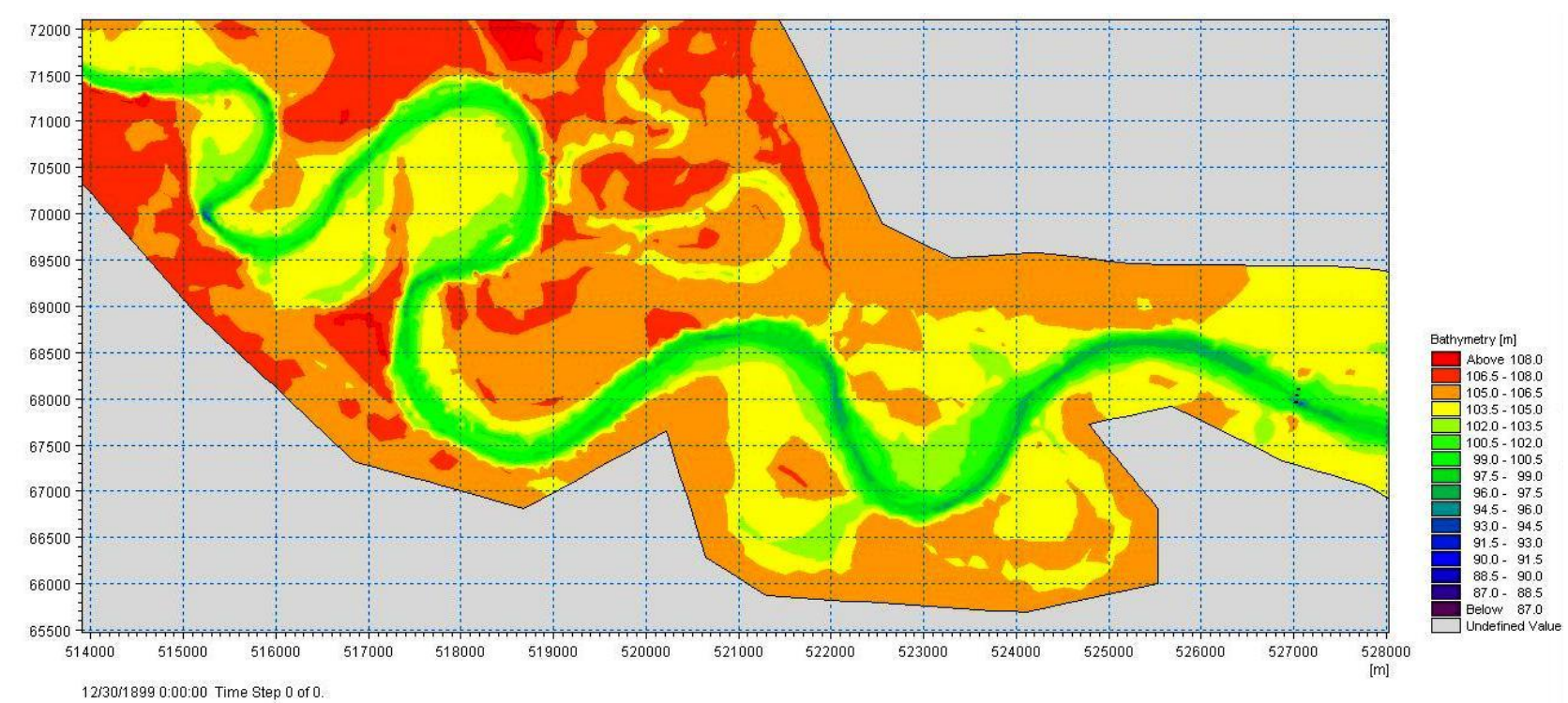

Figure 8 Detail of the DEM for the active floodplain (floodway) of the Drava River

\section{Discussion and results}

\subsection{Zoning the floodway and floodway fringe}

For the identification of channel zones, as proposed by the DDVÍZIG, specific stream velocity, i.e. current velocity multiplied with water depth $\left(\mathrm{m}^{2} \mathrm{~s}^{-1}\right)$, derived from previous modelling, was taken into consideration (Fig. 10).

Specific velocity is more than $6.0 \mathrm{~m}^{2} \mathrm{~s}^{-1}$ for the primary floodway zone, 6.0 to $2.0 \mathrm{~m}^{2} \mathrm{~s}^{-1}$ for the secondary floodplain zone, and $2.0-0.2 \mathrm{~m}^{2} \mathrm{~s}^{-1}$ for the transitional zone. Probably because of the low current velocity of the Drava River, however, the resulting figures proved to be extremely low. Therefore, when establishing the classes of specific velocity from 2D model runs, the distribution of specific velocity was taken into consideration. For more precise zoning, however, the course of the river was divided into two sections. On the section upstream the town Barcs all the four floodplain zones were identified, while in the section downstream no stagnant water area was delimited and, consequently, only three zones could be identified. Downstream Barcs the area of the primary floodway zone was almost exactly equal to that of the secondary zone (19.13 and $19.39 \%$ of total area - Table 2). The velocity classes were also low here (between 0.68 and $2.01 \mathrm{~ms}^{-1}$ for the primary zone and 0.299 to $0.68 \mathrm{~ms}^{-1}$ for the secondary zone in the case of the $3000 \mathrm{~m}^{3} \mathrm{~s}^{-1}$ input discharge) (Table 3). The share of the transitional zone was found to be $28 \%$, while the largest area was occupied by stagnant water (61.48\%), where specific current velocity ranged between 0.074 and $0.299 \mathrm{~m}^{2} \mathrm{~s}^{-1}$.

With lower variation in velocity in the downstream section, the values of specific flow do not show so remarkable differences as on the upstream section. Entrainment force values are not considerably different for the three zones, the average values are between 0.018 and $0.04 \mathrm{kPa}$, while maximum values were similar for all the three zones $(0.18-0.2 \mathrm{kPa})$.

\subsection{Comparison of results of 1D and 2D modelling and DFL}

The differences between the 1D model of the Józsa et al. (2013) and our 2D model (Mike 21) and the differences between the DFL and the MIKE 21 model were calculated for the upper and lower sections of the Drava River. Differences were observed between $1 \mathrm{D}$ and 2D model outputs with the largest difference of $1.16 \mathrm{~m}$ at river kilometre 236. The difference between the DFL and the MIKE 21 model amounted to $3.77 \mathrm{~m}$ on the upper river section (at river $\mathrm{km} \mathrm{183).}$ 
m]

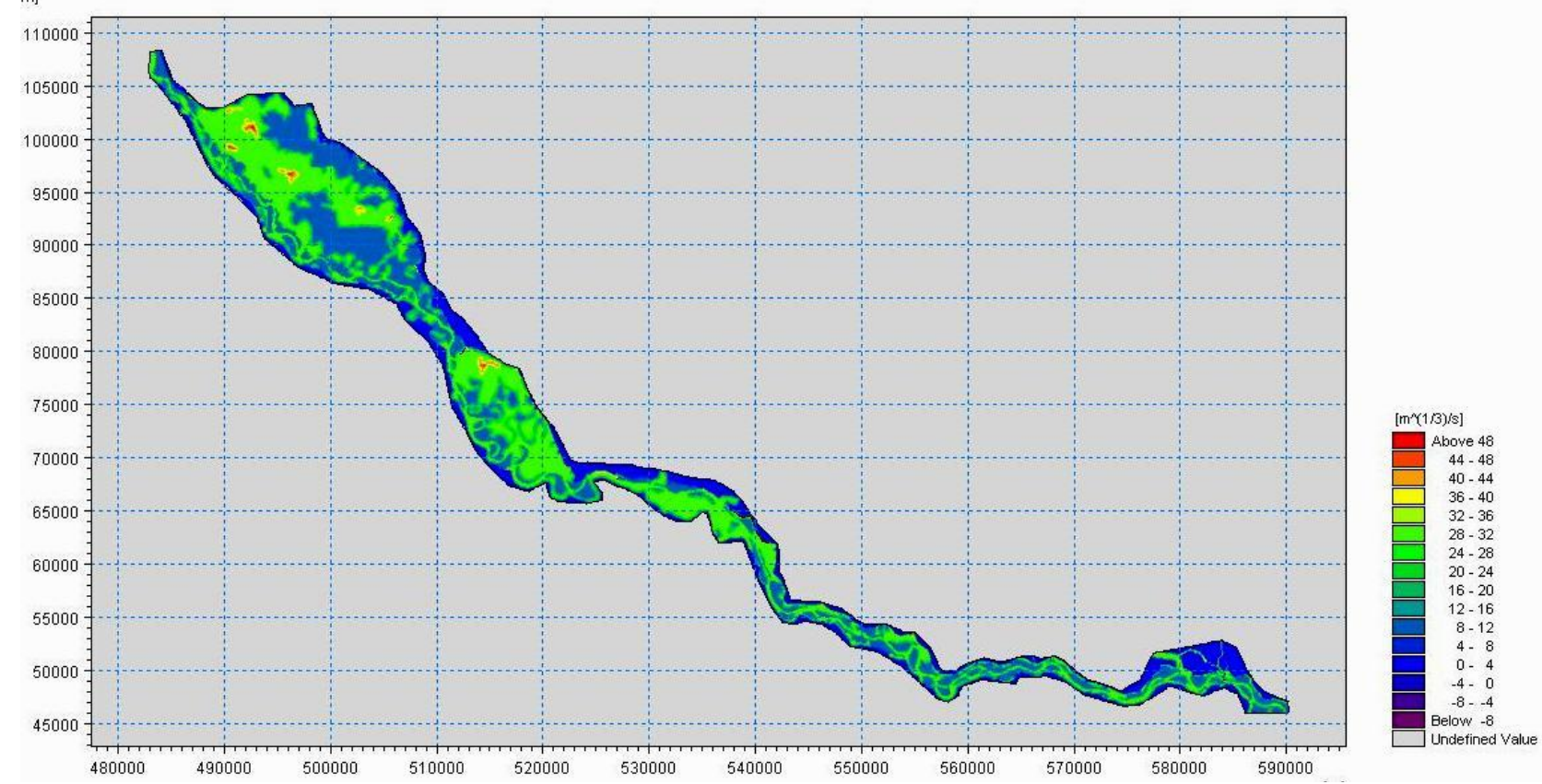

Figure 9 Manning's smoothness map of the floodway of the Drava River

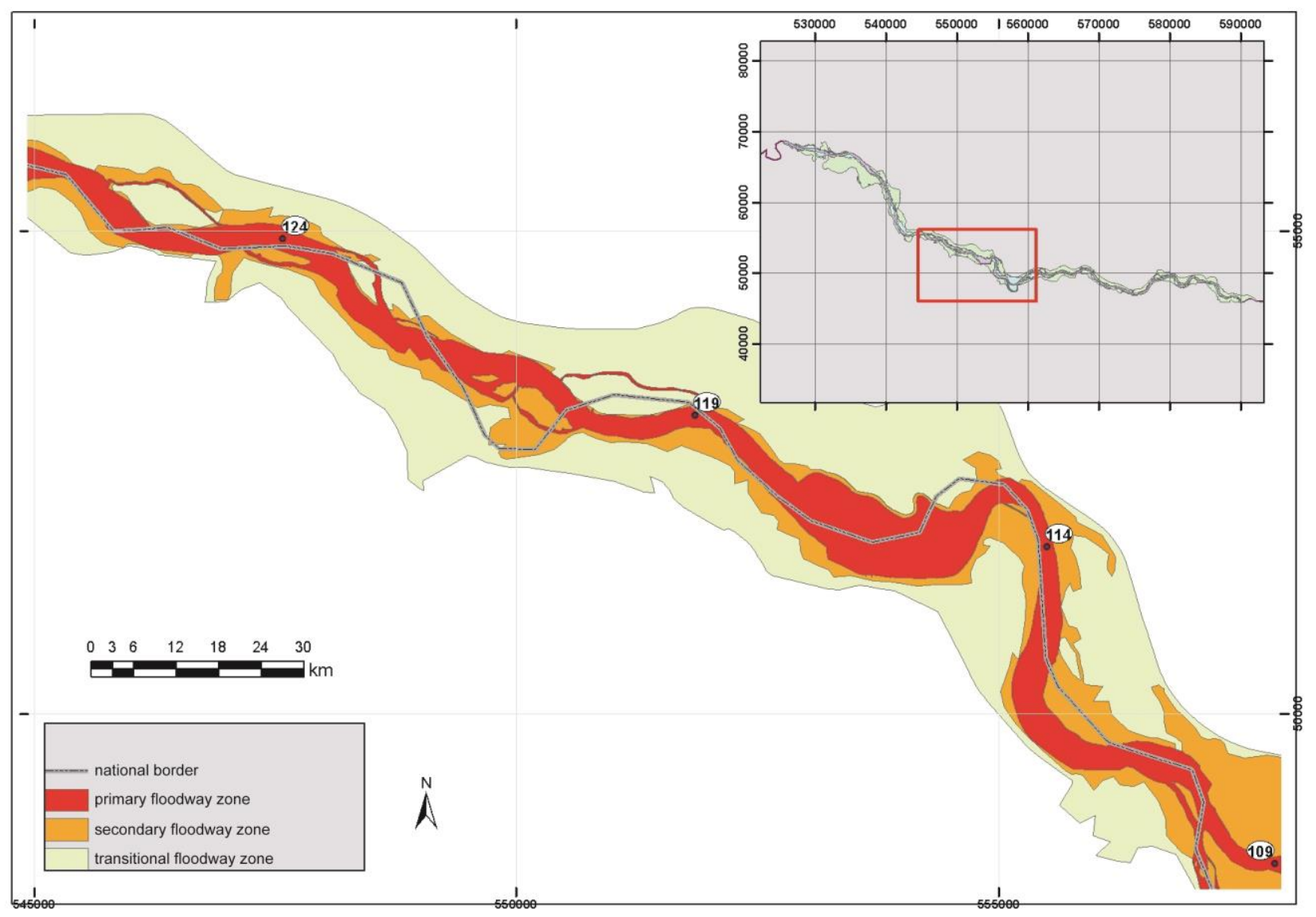

Figure 10 Hydrodynamic zonation of the studied reach of the Drava River and its active floodplain 
Table 1 Definition of zones and construction limitations

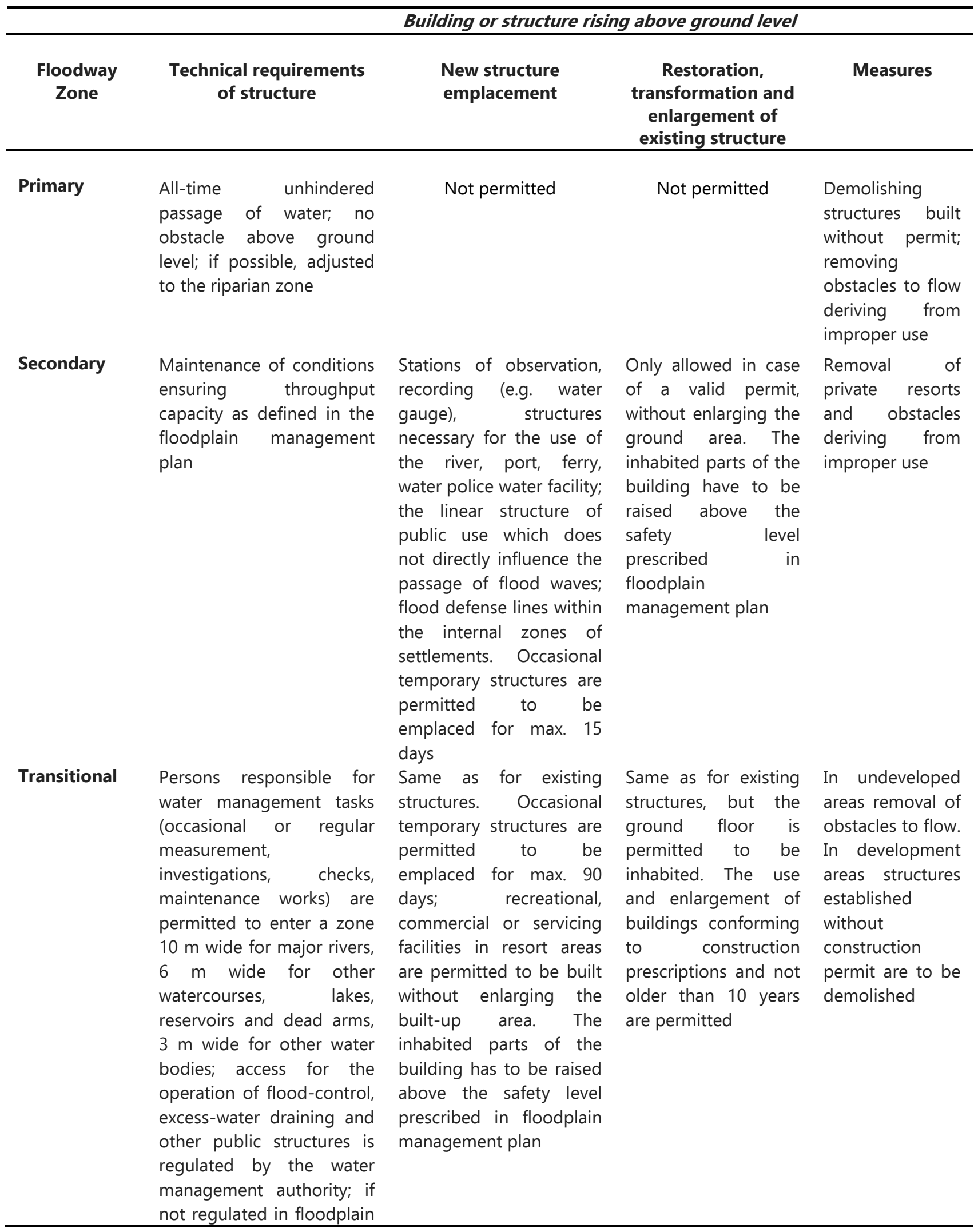




\begin{abstract}
management plans, agricultural use presenting no obstacle to and not endangering the functioning of the riparian zone and the channel is permitted; stations of observation, recording (e.g. water gauge), structures necessary for the use of the river, port, ferry, water police facility are permitted to be emplaced. Seasonally inundated area ensuring sufficient throughput (of culverts, bridges etc.
\end{abstract}

Stagnant Outside the passage way water area of floods. Before approval an analysis has to be performed: focusing on whether the total volume from the stagnant water area does not reduce floodwater storage capacity to an undesirable degree
Same as above. The new building can be erected on undeveloped plots in existing resort area, conforming to prescriptions for zones. The protection of structures located here against floods has to be ensured.

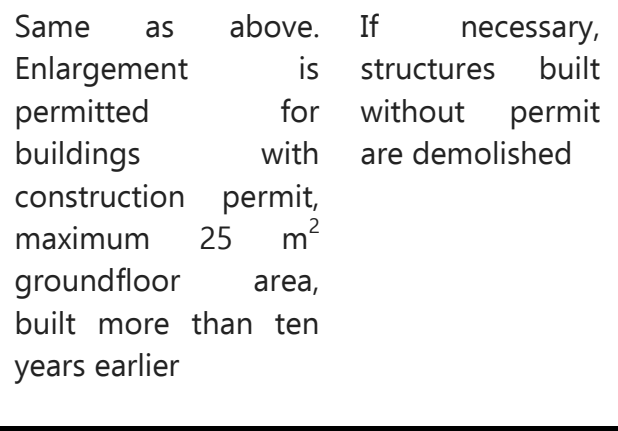

\section{Conclusions}

In general, our 2D model outperformed the 1D model as the latter model provides a more realistic description of actual physical processes. From the results of the 1D modelling of DFL (Torma et al., 2014), long-term trends in the behaviour of the Drava River could only be established if changes in flow conditions induced by neotectonic movements and climate change as well as sedimentation and channel incision trends are incorporated into the model.

Table 2 Areal proportions of zones identified by modelling

\section{Area $\left(\mathbf{k m}^{2}\right)$ Proportion (\%)}

\begin{tabular}{lrr}
\hline Primary floodway zone & 21.125 & 19.13 \\
Secondary floodway & 21.413 & 19.39 \\
zone & 67.896 & 61.48 \\
Transitional zone & 110.435 & 100.00 \\
\hline Total &
\end{tabular}

The variation between DFL and the MIKE 21 model were more moderate on the lower section, but on the upper, less regulated, section higher differences were found. River behaviour is more unpredictable along this section, which is manifested in comparisons of our findings with both the 1D model and the DFL. The major shortcoming of the employed 2D model was the need for reduced spatial resolution (25-meter for the floodplain) that significantly worsened output data quality. Although the 2D MIKE 21 model performed better than the 1D model, 3D models would provide more accurate outputs than any $2 \mathrm{D}$ models. Therefore for futre floodplain simulations and hydrologic-hydraulic analyses, if increased computational capacity is available, the use of 3D models will be indispensable.

According to the results of our 2D model, we delineated four major flow zones upstream Barcs, and three between Barcs and Drávaszabolcs. Due to 
the confined floodplain downstream Barcs, no stagnant water area was delimited there. Specific velocities were markedly lower than stated in the Government Decree $\left(0.2\right.$ to $\left.6.0 \mathrm{~m}^{2} \mathrm{~s}^{-1}\right)$, and ranged between 0.089 and $3.476 \mathrm{~m}^{2} \mathrm{~s}^{-1}$, and 0.075 and 2.01 $\mathrm{m}^{2} \mathrm{~s}^{-1}$, upstream and downstream Barcs, respectively. The primary and secondary conveyance zones covered a combined area of about $40 \%$ of the entire floodplain, while the remaining $60 \%$ included both the transitional and stagnant water zones upstream Barcs and solely the transitional zone downstream Barcs. If stream power increases due to the intensification of the hydrologic cycle, on the section downstream of Barcs, where the channel is more strictly regulated, lateral erosion will be reduced, and channel incision will become predominant.

Flood waves significantly contribute to lateral channel shift with rapid bank erosion. At the same time, within meanders, intense deposition is observed in times of lower flow. The bars rising above mean water level are occupied by pioneer vegetation and this hinders fluvial erosion.

The findings of the model runs are unsuitable to draw conclusions on the trend of undoubtedly observed vertical channel change (incision). The model was run for the impacts of a single flood wave of $3,000 \mathrm{~m}^{3} \mathrm{~s}^{-1}$.

Table 3 Basic hydrodynamic properties of the identified zones

\begin{tabular}{lcccccc}
\hline & $\begin{array}{c}\text { Average } \\
\text { model current } \\
\text { velocity } \\
\left(\mathbf{m ~ s}^{-1}\right)^{*}\end{array}$ & $\begin{array}{c}\text { Maximum } \\
\text { model current } \\
\text { velocity } \\
\left(\mathbf{m ~ s}^{-1}\right)^{*}\end{array}$ & $\begin{array}{c}\text { Average } \\
\text { entrainment } \\
\text { force } \\
(\mathbf{k P a})\end{array}$ & $\begin{array}{c}\text { Maximum } \\
\text { entrainment } \\
\text { force } \\
(\mathbf{k P a})\end{array}$ & $\begin{array}{c}\text { Average } \\
\text { specific flow } \\
\left(\mathbf{m}^{2} \mathbf{~ s}^{-1}\right)\end{array}$ & $\begin{array}{c}\text { Maximum } \\
\text { specific flow } \\
\left(\mathbf{m}^{2} \mathbf{~ s}^{-1}\right)\end{array}$ \\
\hline $\begin{array}{l}\text { Primary } \\
\text { floodway zone }\end{array}$ & 0.68 & 2.01 & 0.018 & 0.18 & 3.3 & 11.26 \\
$\begin{array}{l}\text { Secondary } \\
\text { floodway zone }\end{array}$ & 0.41 & 2.99 & 0.04 & 0.20 & 0.9 & 8.09 \\
$\begin{array}{l}\text { Transitional } \\
\text { zone }\end{array}$ & 0.075 & 0.299 & 0.020 & 0.200 & 0.085 & 4.350 \\
\hline
\end{tabular}

*Zoning was based on model current velocity and local hydrographic conditions

Long-term vertical changes equally reflect the impacts of alterations in stream power, tectonic movements, climate changes and human interventions manifested in changes in water discharge and current velocity (Lovász, 2014; Kiss and Andrási, 2014).

With the intensifying hydrological cycle and the extreme temporal precipitation distribution (Nováky and Bálint, 2013) higher-than-usual flood waves are expected to occur more frequently. In September 2014, for instance, the preventive release of discharge stored in the reservoirs of the Croatian hydroelectric plants successfully reduced the flood peak which had been envisioned to surpass the previous record flow in 1972. Similarly, with more sophisticated, model-based flow estimates, operation of the Croatian Hydropower plants may also be optimized in the future.
When most future climatic scenarios are considered, flow values, exceeding $3,000 \mathrm{~m}^{3} \mathrm{~s}^{-1}$ are expected with a shorter return period. Despite the incision of the river, higher flood levels are expected for the river due to it more extreme behaviour and water regime. Consequently, development in the transitional zone should limited, or their insurance costs should be charged accordingly. Nonetheless, environmental consciousness and ecological concerns should also enjoy priorities in both floodway zones and also in the transitional zones, while wetland restoration actions and sustainable water management are strongly advised in the broader floodplain.

Recent technological and methodological developments in the field of environmental modelling, provides valuable indicators for decision support actions and the stakeholders' challenges (Klug and Kmoch, 2015). Exact delineation of the 
floodways, transitional zones and floodplains, based on the digital terrain models and hydrological modeling, enhances the future development of appropriate water management approaches and policies, and may provide adequate approach for multi-purpose decision making and adequately supports operational actions. We believe that strategies of these types are especially crucial when multi-national water management authorities, with different motivation and economic interests, are forced to collaborate in order to elaborate best management practices. In correspondence with flow modeling, sediment transport models are further optimized and may provide more accurate results for channel development and estimation of sedimentation rates behind dams. When flow models are combined with sedimentation models, information may also be gathered on sand bar locations and development rates, as well as more detailed information will be available on navigation routes and pathways on the Drava.

\section{Acknowledgements}

The authors are grateful to Gábor Horváth at the South Transdanubian Water Management Directorate for providing data to our project. The project was partly supported by the National Scientific Research Fund (contract no 104552) and the "SROP-4.2.2.C-11/1/KONV-2012-0005" grant (Well-being in the Information Society).

\section{References}

Bates PD, Anderson MG, Baird L, Walling DE, Simms D. 2006. Modelling floodplain flows using a twodimensional finite element model. Earth Surface Processes and Landforms 17(6): 575-588. DOI: 10.1002/esp.3290170604.

Babaeyan-Koopae K, Ervine DA, Pender G. 2003. Field measurements and flow modeling of overbank flows in River Severn, U.K. Journal of Environmental Informatics 1(1): 28-36.

Bedient PB, Huber WC. 2002. Hydrology and floodplain Analysis. 3rd edition Prentice-Hall Upper Saddle River NJ. 763 p.

Bertalan L, Tóth AC, Szabó G, Nagy G, Kuda F, Szabó Sz. 2016. Confirmation of a theory: Reconstruction of an alluvial plain development in a flume experiment. Erdkunde 70(3): 271-285.

Chen L. 2010. Finite Volume Methods. Department of Mathematics, University of California, Irvine, CA. 7 p. http://www.math.uci.edu/ chenlong/226/FVM.pdf

Czigány Sz, Gyenizse P, Lovász Gy. 2007. The effect of Holocene tectonics on the subsidence of the Danube's riverbed between Rajka and Budapest. Hungary Journal of Hydrology and íhydromechanics 55(2): 135-139.

DDKÖVIZIG 2000. A Dráva vízrajzi atlasza (Hydrographical Atlas of the Drava River). South-Transdanubian Environmental. Protection and Water Management Directorate, Pécs. CD publication.

DHI 2014. MIKE 21 Flow Model FM. Parallelization using GPU. Benchmark report. Hørsholm, Denmark. 42 p.

http://www.mikebydhi.com/ /media/Microsite_MIKEbyD HI/Publications/PDF/GPU_Benchmarking.ashx

FEMA 2013. Floods and floodplain management. Federal Emergency Management Agency, Washington, DC. 32 p. http://www.fema.gov/media-library-data/ 20130726-1539-20490-2034/nfip_sg_unit_1.pdf.

Accessed 12 December 2014.

Gee DM, Anderson MG, Baird L. 1990. Large-scale floodplain modeling. Earth Surface Processes and Landforms 15: 513-523.

Government of Hungary 2014. 83/2014. (III. 14.) Korm. Rendelet a nagyvízi meder, a parti sáv, a vízjárta és a fakadó vizek által veszélyeztetett területek használatáról, hasznosításáról, valamint a folyók esetében a nagyvízi mederkezelési terv készítésének rendjére és tartalmára vonatkozó szabályokról (Governmental decree on the utilization of floodways, riparian zones, waterlogged areas and areas endangered by springing water as well as on the regulation and contents of floodway management planning for rivers).

http://net.jogtar.hu/jr/gen/hjegy_doc.cgi?docid=A140008 3.KOR

Grêt-Regamey A, Weibel B, Bagstad KJ, Ferrari M, Geneletti D, Klug H, Schirpke U, Tappeiner U. 2015. On the effects of scale for ecosystem services mapping. In: PLOS One, 9(12): 1-26; DOI http://dx.doi.org/10.1371/journal.pone.0112601.

Johnson LE. 2008. Geographic Information Systems in Water Resources Engineering. CRC Press, Boca Raton, FL. 316 p.

Józsa J, Krámer T, Baranya S, Szilágyi J. 2013. Korszerü módszerek az árvizek részletgazdag helyszíni mérésében és numerikus modellezésében: júniusi tapasztalatok, eredmények és a továbblépés irányai (New methods for detailed field measurements and numeric modeling of floods: experience and findings 
in June and perspectives of furhtrer developments). Paper presented at the 39th Meteorological Scientific Days, Budapest, 21-22 November 2013.

http://www.met.hu/doc/rendezvenyek/metnapok013/04_Jozsa.pdf

Jung HC, Jasinski M, Kim J-W, Shum CK, Bates P, Neal J, Lee $H$, Alsdorf D. 2012. Calibration of twodimensional floodplain modeling in the central Atchafalaya Basin Floodway System using SAR interferometry. Water Resources Research 48. W07511. DOI: 10.1029/2012WR011951

Kiss T, Andrási G. 2014. Morphological classification and changes of islands on the Dráva River, HungaryCroatia. Carpathian Journal of Earth and Environmental Sciences 9(3)

Klug $\mathrm{H}$, Kmoch A. 2015. Operationalizing environmental indicators for real time multi-purpose decision making and action support. Ecological Modelling 295: 66-74.

Krámer T, Józsa J. 2004. An overview of river floodplain modelling. Department of Hydraulic and Water Resources Engineering, Budapest University of Technology and Economics, Budapest. $15 \mathrm{p}$.

http://vit.bme.hu/targyak/mundus_3rd/vedett/mundus_flo od_simulation.pdf

Liu YB, De Smedt F. 2005. Flood modeling for complex terrain using GIS and remote sensed information. Water Resources Management 19: 605-624. DOI: 10.1007/s11269-005-6808-x

Lovász Gy, Gyenizse P, Czigány Sz. 2007. Channel depth changes of the Danube along its Hungarian stretch. In: Halasi-Kun GJ and Stekanerova V. (ed.) Pollution and Water Resources: Environmental Problems in US and Central Europe including social Aspects of both Areas. 324 p. Bratislava: Columbia University Press, 2007. pp. 49-62. (Columbia University Seminar Proceedings; 2006-2007.) Vol. XXXVII (ISBN:978-8089139-12-5)

Marriott SB, Alexander J. 1999. Floodplains: Interdisciplinary Approaches. Geological Society Special Publications No. 163. The Geological Society, London $336 \mathrm{p}$.

Mavriplis DJ. 2008. Unstructured-Mesh Discretizations and Solvers for Computational Aerodynamics. AIAA Journa/46(6): 1281-1298.

Mishra A, Anand A, Singh R, Raghuwanshi NS. 2001. Hydraulic modeling of Kangsbati Main Canal for performance assessment. Journal of Irrigation and Drainage Engineering 127(1): 27-34.

Novák TJ, Incze J, Rózsa P. 2013. Quantifying anthropogeomorphological transformation by using the concept of "hemeromorphy" a case study from
Hungary, In: 8th IAG International Conference on Geomorphology Abstract Book, Paris 2013 p. 466.

Nováky B, Bálint G. 2013. Shifts and modification of the hydrological regime under climate change in Hungary. In: Singh BR. (ed.): Climate Change Realities, Impacts Over Ice Cap, Sea Level and Risks. InTech, Rijeka. 163-190. DOI: 10.5772/54768.

Purger JJ. (ed.) 2013. Biota and rehabilitation of four Drava River side-branches in Hungary. Danube-Drava National Park Directorate, Pécs. 164 p.

Rózsa P, Novák T. 2011. Anthropogeomorphological Landscape Transformation of the Tokaj Nagy-Hill - a case study for quantifying the process, In: Hradecký J and Šilhán K. (eds.)(2011): Carpatho-Balkan-Dinaric Conference on Geomorphology, Book of Abstracts, ISBN 978-80-7368-444-0, Ostravice (Czech Republic), 51-52.

http://www.ddnp.hu/_user/browser/File/downloads/Drava _mellekegak_konyv.pdf

Selvanathan S, Dymond R. 2010. FloodwayGIS: An ArcGIS Visualization Environment to Remodel a Floodway. Transactions in GIS 14(5): 671-688. DOI: 10.1111/j. 1467-9671.2010.01225.x.

Stewart MD, Bates PD, Anderson MG, Price DA, Burt TP. 1999. Modelling floods in hydrologically complex lowland river reaches. Journal of Hydrology 223: 85-106.

Spalart PR. 2009. Detached-eddy simulation. Annual Review of Fluid Mechanics 41: 181-202.

Szabó Sz, Novák T, Elek Z. 2012. Distance models in ecological network management: A case study of patch connectivity in a grassland network. Journal for Nature Conservation 20 (5):293-300 (http://www. sciencedirect.com/science/article/pii/S161713811200 057X - aff0010)

Tate E, Maidment D, Olivera F, Anderson D. 2002. Creating a Terrain Model for Floodplain Mapping. Journal of Hydrological Engineering 7(2): 100-108.

Toombes L, Chanson H. 2011. Numerical Limitations of Hydraulic Models. 34th IAHR World Congress Balance and Uncertainty, June 26 to July 1, 2011, Brisbane, Queensland, Australia.

Torma P, Krámer T, Józsa J. 2014. Hidrodinamikai modellel végzett előrejelző számítások a Dráva és Mura folyókra a 2014. szeptemberi árvíz idején (Forecasts of the 2014 September floods on the Drava and Mura Rivers using hydrodynamic modelling). Manuscript research report. Department of Hydraulic and Water Resources Engineering, Budapest University of Technology and Econmics, Budapest.

Weber WJ Jr., DeGiano FA. 1996. Process Dynamics in Environmental Systems. John Wiley and Sons. 943 p. 